\title{
DECISION ANALYSIS OF ANTIBIOTIC USE
}

\author{
ANAMARIA BOBOIA ${ }^{1 *}$, LAURA SILVIA FLOREA ${ }^{2}$, ADINA TURCU-STIOLICA $^{3}$, ADRIANA $^{2}$ \\ ELENA TĂEREL ${ }^{4}$, CRISTINA RAIS ${ }^{4}$, CORNELIA REVNIC ${ }^{5}$, ANCA FLOREA ${ }^{6}$, NICOLETA \\ SIMONA VEDEANU ${ }^{7}$, CRISTINA NASTASA ${ }^{8}$, OVIDIU ONIGA ${ }^{8}$
}

\author{
${ }^{1}$ Department of Pharmaceutical Management, Marketing and Legislation, Faculty of Pharmacy, "Iuliu Hatieganu” University \\ of Medicine and Pharmacy Cluj-Napoca, 8 Victor Babeș Street, 400012, Cluj-Napoca, Romania \\ ${ }^{2}$ Department of Quality Assurance, TIS Farmaceutic, 16 Road of Industries, 032895, Bucharest, Romania \\ ${ }^{3}$ Department of Pharmaceutical Management and Marketing, Faculty of Pharmacy, University of Medicine and Pharmacy \\ Craiova, 2 Petru Rareș Street, 200349, Craiova, Romania \\ ${ }^{4}$ Department of Pharmaceutical Management and Marketing, Faculty of Pharmacy, "Carol Davila” University of Medicine \\ and Pharmacy, 6 Traian Vuia Street, 020956, Bucharest, Romania \\ ${ }^{5}$ Department of Mathematical and Computer Science, Faculty of Pharmacy, "Iuliu Haţieganu” University of Medicine and \\ Pharmacy Cluj-Napoca, 6 Pasteur Street, 400349, Cluj-Napoca, Romania \\ ${ }^{6}$ Department of Analytical Chemistry and Instrumental Analysis, Faculty of Pharmacy, “Iuliu Hatieganu” University of \\ Medicine and Pharmacy Cluj-Napoca, 4 Pasteur Street, 400349, Cluj-Napoca, Romania \\ ${ }^{7}$ Department of Pharmaceutical Physics, Biophysics, Faculty of Pharmacy, "Iuliu Haţieganu” University of Medicine and \\ Pharmacy Cluj-Napoca, 6 Pasteur Street, 400349, Cluj-Napoca, Romania \\ ${ }^{8}$ Department of Pharmaceutical Chemistry, Faculty of Pharmacy, "Iuliu Haţieganu” University of Medicine and Pharmacy \\ Cluj-Napoca, 41 Victor Babeş Street, 400012, Cluj-Napoca, Romania
}

*corresponding author: aboboia@umfcluj.ro

Manuscript received: December 2019

\begin{abstract}
The research objectives have been analysing the profile of the antibiotics consumers in Romania, the causes and risks of the irrational use of antibiotics, the way of their purchasing from community pharmacies in the country and the proposal of a correct and efficient information modality of the population on the risks of irrational antibiotics consumption. An instrumental marketing research has been conducted, based on a survey using a questionnaire distributed to a representative sample, the evaluation being achieved in all counties in Romania. The obtained results have highlighted the main causes of the irrational use of antibiotics: their administration in conditions that don't require such a treatment, population's inability to clearly and accurately associate the antibiotic with the affections that it treats, sometimes the insufficient counselling provided by physicians and pharmacists regarding the posology and the risks of antibiotics consumption, and getting antibiotics from community pharmacies, in some cases, without presenting a medical prescription. In order to educate the population, an original, interactive and suggestive booklet has been accomplished, to correctly inform patients about antibiotics and the treated diseases, so they would understand the risks implied by the irrational use of antibiotics. The study results have indicated a series of problems related to the antibiotics' use in Romania. It is very important to be aware of the risks associated with an irrational consumption of antibiotics, which is the main factor of the emergence of the bacterial resistance. One proposed solution has aimed to inform the public including through the elaboration and dissemination of concludent informative materials.
\end{abstract}

\section{Rezumat}

Obiectivele cercetării au constat în analizarea profilului consumatorului de antibiotice din România, a cauzelor şi riscurilor aferente utilizării iraționale de antibiotice, a modului de procurare a acestora din farmaciile comunitare din țară, precum şi propunerea unei modalităţi de informare corectă şi eficientă a populaţiei privind riscurile consumului iraţional de antibiotice. S-a realizat o cercetare de marketing instrumentală, având la bază o anchetă efectuată cu ajutorul unui chestionar distribuit unui eşantion reprezentativ, cadrul de selecţie fiind la nivelul tuturor judeţelor din România. Rezultatele obținute au reliefat că principalele cauze ale consumului irațional de antibiotice sunt: administrarea lor în afecțiuni care nu necesită un astfel de tratament, incapacitatea populaţiei de a asocia clar şi corect termenul de antibiotic cu afecțiunile pe care acesta le tratează, uneori consilierea insuficientă oferită de medici și farmacişti privind posologia şi riscurile aferente consumului de antibiotice, precum şi procurarea acestora din farmaciile comunitare, în unele cazuri, în lipsa prezentării unei prescripții medicale. În vederea educării populaţiei, s-a realizat o broşură originală, interactivă și sugestivă, care să ajute pacienții să înțeleagă ce este un antibiotic, care sunt afecțiunile pe care le tratează și să conștientizeze riscul la care se expun în urma consumului irațional de antibiotice. Rezultatele studiului au indicat o serie de probleme corelate cu utilizarea antibioticelor în România. Este foarte importantă conştientizarea riscurilor asociate consumului irațional de antibiotice, acesta reprezentând principalul factor al dezvoltării rezistenței bacteriene. O soluţie propusă vizează educarea populaţiei, inclusiv prin elaborarea şi distribuirea către pacienţi a unor materiale informative concludente.

Keywords: antibiotics use, decision analysis, questionnaire-based investigation, marketing research, pharmacies 


\section{Introduction}

Serious infections caused by resistant bacteria to commonly used antibiotics have become a major global healthcare problem in the $21^{\text {st }}$ century $[1,7$, 24]. There are many causes which led to this dangerous phenomenon of bacterial resistance, e.g.: the excessive use of antibiotics, the inadequate indication and posology (doses and treatment duration), the use of these drugs in the veterinary practice. As known, one major reason for the emergence of antibiotic resistance is their incorrect use by the patients and excessive prescribing by some doctors [2, 28]. Self-administering non-prescribed antibiotics, when not needed, is still one of the reasons why bacteria develop resistance to these drugs. In Romania, as in other European countries, antibiotics are dispensed from pharmacies, usually based on a medical prescription, a measure precisely taken to stop the abusive administration of these drugs and the emergence of resistance.

The alarming incidence of the cases of increasing bacterial resistance to antibiotics is a matter of high relevance and interest. Some of the bacteria, such as methicillin resistant Staphylococcus (MRSA), vancomycin resistant Enterococcus (VRE), penicillin resistant Streptococcus pneumoniae (PRP), Neisseria gonorrhoeae, ESBL-producing Enterobacteriaceae, Clostridium difficile, Pseudomonas aeruginosa, Mycobacterium tuberculosis are causing great problems [4, 6, 8, 12, 20-22].

Antibiotic resistance, driven by the antibiotic consumption, is a growing global health threat [16]. In the developing countries, the socio-economic and political factors which contribute to the rise in the prevalence of antibiotic resistance include: the lack of surveillance of resistance development, the poor quality of available antibiotics, the clinical misuse and the ease of availability of antibiotics [7]. Antibiotics are also eliminated in waste waters, their presence in environmental samples being a factor that contributes to antibiotic resistance [14]. In Europe, the major factors among the general public driving antibiotic resistance are the lack of public knowledge and awareness, the access to antibiotics without prescription, the attitude and the perception of prescribers and dispensers, the inadequate medical training, the pharmaceutical promotion, the lack of rapid and sufficient diagnostic tests, and the patientdoctor interaction as major factors among healthcare providers [19].

While in most countries in Europe, the antibiotic resistance to bacteria has declined, Romania is experiencing a real increase in bacterial resistance to antibiotics, according to the new statistics from the European Centre for Communicable Diseases Control [13]. A European report ranks Romania the first place in obtaining antibiotics without a medical prescription.
What is worrying is that resistance to antibiotics is a phenomenon related to the manner and magnitude of their use and their inappropriate use is the main cause of antibiotic resistance [11, 23, 25].

As part of a wide European public health initiative, the European Centre for Disease Prevention and Control along with the European Union's health authorities launched the European Antibiotic Information Day, marked annually on 18 November. Romania joined the efforts of the European Centre for Disease Prevention and Control, to bring the problem of antibiotic resistance to the attention of specialists, of factors involved in the production, prescription and distribution of antibiotics, as well as to the general public [13].

The prudent use of antibiotics can help stop the development of resistant bacteria and ensure the effectiveness of antibiotics in the future.

The aim of the present research was analysing the profile of the antibiotic consumer in Romania, the awareness about the risk to the consumer from irrational use of antibiotics and the way of obtaining antibiotics from the pharmacies. At the same time, the paper aims to find a way to efficiently inform patients concerning the risk of irrational consumption of antibiotics.

\section{Materials and Methods}

\section{Materials}

An instrumental marketing research was conducted, based on a questionnaire survey. The questionnaire contained closed dichotomic questions or multiple answers and a suggestion section that allowed responders to provide other opinions regarding the use of antibiotics. The first questions aimed at obtaining general information about the respondents: age, gender, origin environment, education level, occupation. The other questions were asked in order to understand the behaviour of the antibiotic consumer.

Each question that was found in the questionnaire had a precise purpose for a more complex and revealing analysis of the awareness of the irrational consumption of antibiotics among the population; it has also tried to analyse whether the information held by the population is sufficient or not in order to prevent this problem. The distribution of the questionnaire was realised both via the Internet (e-mail, social networks) and on printed support. The program used to conceive the questionnaire and store the collected data was "Google Docs". The questionnaire was distributed to 976 people, from April to June 2016. The evaluation was performed in all counties in Romania and people aged over 18 years, were questioned.

The questionnaire method. The usefulness of the questionnaire is given by the different categories of information provided: the hierarchy of needs, attitudes, consumption habits, consumer motivations and socio-demographic factors. The information 
obtained from the questionnaire is a quantitative and qualitative one; it can be detailed according to a certain criterion, so as to allow in-depth knowledge of some aspects. In order to ensure an optimal use of the questionnaire, there have been elaborated the instructions for its completing, which ensure the unitary character of the information [9, 10, 15, 17, 27]. Instructions for filling-up the questionnaire have been provided to the responders. There have been indicated to the respondents that for each question of the questionnaire, they would tick one or more boxes, depending on their appreciation. Also, the confidentiality of the respondents' answers/data was insured.

The sampling method. The sampling was the method in which the sample was chosen in such a way that each individual of the entire population has an equal probability to be included in the sample, the method for the selection of the sample was random, allowing the assessment of the results based on the probability theory and the quantification of the risk of sampling. The sample for our survey was chosen to ensure all strata contribute, as for example: all areas of the country, all social backgrounds, all levels of training, and both genders. The questionnaire was distributed to 976 people so that the probability of being in one category or another was the same. Descriptive statistics, as frequency and percentages, were used to summarize data. The variables were categorical and they were analyzed with Microsoft Excel 2010. We have considered the standard error of 0.05 .

\section{Results and Discussion}

A total of 301 questionnaires were included in the study. A response rate of $30.84 \%$ was attained.

The results of the marketing instrumental research conducted, based on the answers received from the survey conducted among the adult population in Romania, are presented, analysed, interpreted and discussed further.

The first set of questions (1a-e) constitutes the general data on the questioned subject, starting with age and gender, which were included in the questionnaire to establish the profile of the Romanian antibiotic consumer.

Of 301 participants, 69\% were people aged between 18 and 30 years, due to the preponderant electronic distribution of the questionnaire (Figure 1).

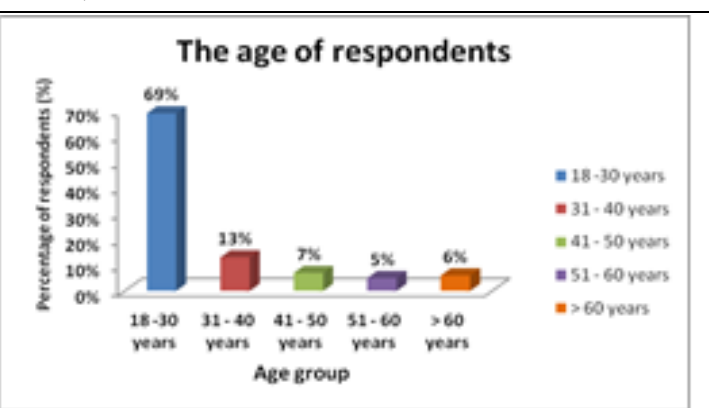

Figure 1.

Results of the question 1a) Respondents' age

In terms of gender repartition (question 1b), a percentage of $67 \%$ of respondents is represented by women and $33 \%$ by men.

The question 1c) ("the environment in which you live") is important because people living in rural areas can have less access to information than those living in the urban environment and thus explain the lack of knowledge regarding antibiotics and the risk of their administration in an inappropriate manner. Another problem of the rural environment is the fact that the number of medical offices is much lower than in the urban environment, often existing only one medical office for several villages located at distance, which can lead to the procurement of antibiotics in the absence of a medical prescription issued by a physician. On the other hand, in the urban area, the access to information is better, and therefore, those living in a city are more inclined to consider that their own documentation, regarding their condition of suffering and its related medication, is sufficient. In the research carried out, the percentage of respondents in the rural area was of $21 \%$ and of those in the urban environment of $79 \%$.

Question 1d) refers to the "level of education" (Figure 2). This is important due to the fact that most of those with higher education are more informed and more interested in these issues than those with a lower level of education.

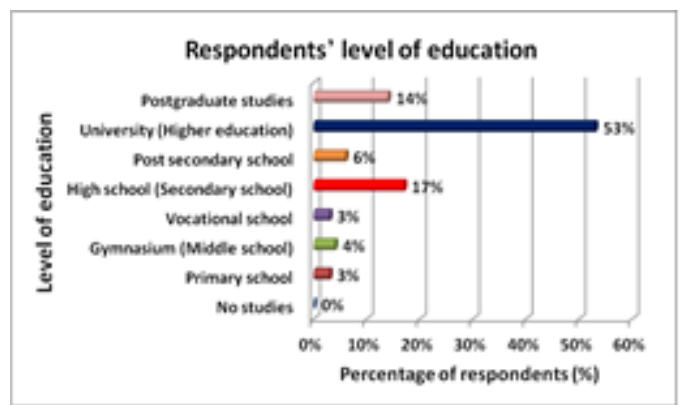

Figure 2 .

Results obtained at the question 1d) "Level of education" 
From Figure 2 it is noticed that those with higher education, university and postgraduate studies formed the majority, with a percentage of $67 \%$ of respondents, followed by those who graduated a high school, with a percentage of $17 \%$.

"Occupation" is the topic of the question numbered $1 \mathrm{e}$ in the questionnaire and it has the role of revealing the purchasing power of each questioned subject (Figure 3). People with higher incomes, such as those professionally active, buy more, including drugs, as opposed to those with lower incomes, such as retiree, unemployed or students.

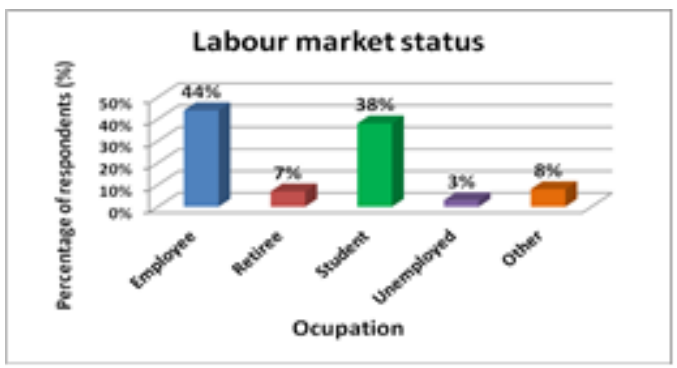

Figure 3.

The results obtained in question 1e) "Occupation"

From Figure 3 we can depict that the most numerous respondents were employees and students, in percentage of $44 \%$ and $38 \%$, respectively.

Question no. 2 of the questionnaire aimed at understanding the behaviour of patients when they have a health problem (Figure 4).

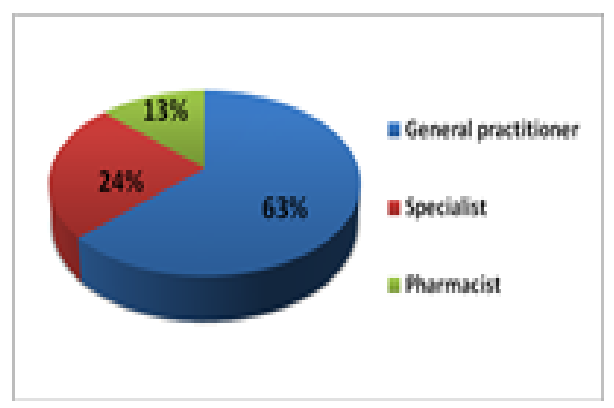

Figure 4.

The results obtained at the question: "When you have a major health problem requiring medical treatment, first you address to"

From Figure 4 results that among those surveyed, the majority, i.e. $63 \%$, addressed to the general practitioner if they experienced a major health problem, which shows a high level of awareness of the importance of medical consulting among the population; it can be noted that only $13 \%$ addressed to the pharmacist, which makes us expect a low percentage of those who administer medicines irrationally.

The following question was introduced in the questionnaire to find out the meaning of the word "antibiotic" for each person (Figure 5).

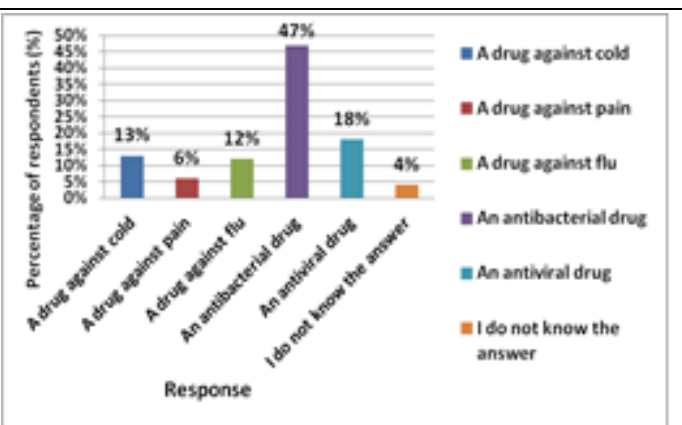

Figure 5.

The results obtained at the question: "What does antibiotic mean to you?"

A percentage of $47 \%$ of the respondents have correct information, namely that the antibiotic is an antibacterial medicine. However, $18 \%$ of the respondents incorrectly placed the antibiotic in the class of antiviral drugs, a common mistake, also $13 \%$ of respondents consider it a drug against cold and $12 \%$ of them consider it a drug against flu; $6 \%$ of respondents consider it a drug for pain and $4 \%$ do not know the answer to this question. From this, it can be deduced that many of the respondents do not know the correct meaning of the term "antibiotic" and that they need additional counselling in order to explain them, as clearly and simply as possible, what is an antibiotic.

To the question of how antibiotics are used, the results presented in Figure 6 were obtained.

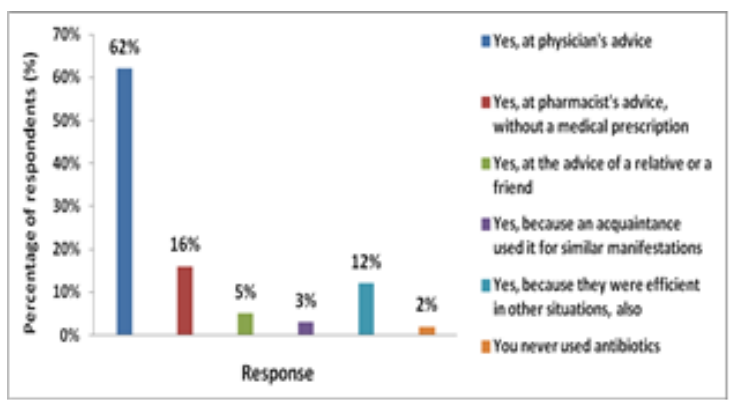

Figure 6.

The results obtained in question: "Do you use antibiotics?"

As it can be observed from Figure 6, the majority, namely $62 \%$, use antibiotics at the recommendation of the physician, which shows their responsibility and awareness of the importance of establishing a diagnosis by a qualified medical practitioner; $16 \%$ take into account the pharmacist's recommendation, which is also important, but not sufficient, because antibiotics treat bacterial disorders, which in many cases cannot be detected based on the simple query of the patient. Therefore, in the absence of a specialist's consultation, of a thorough investigation and of a correct diagnosis, such treatment can have serious repercussions on the patient's health. A 
percentage of $12 \%$ use them because they were effective in other situations, which is a wrong attitude, in the absence of a medical investigation. $5 \%$ of respondents stated that they initiated an antibiotics treatment at the advice of a friend or a relative. This situation is less common, but it is not to be neglected, because the irrational use of the antibiotic occurs. $3 \%$ of respondents use antibiotics because these were previously used by people with similar illnesses, this being a totally wrong attitude of the patients. As each person is different from another, the illnesses are different from case to case, making it impossible to overlap a diagnosis or a treatment response with another just based on the symptomatology.

The next question is meant to find out for which disorders the respondents used antibiotics (Figure 7).

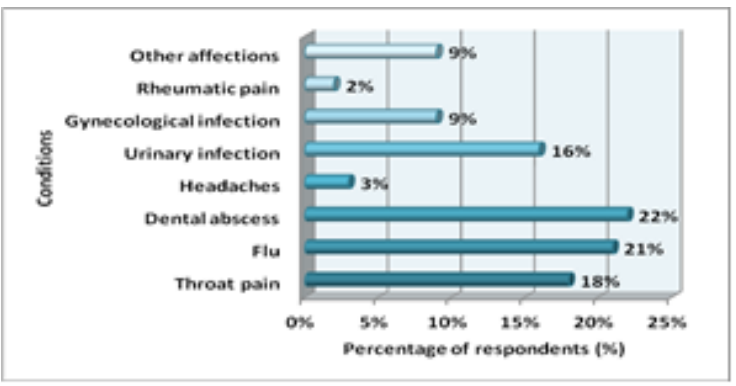

Figure 7.

The results obtained at the question: "What are the conditions for which you have used antibiotics?"

This question is the first which clearly reveals that antibiotics are irrationally used. Even though $22 \%$ of respondents rightly claim that administer antibiotics to treat a dental abscess, $16 \%$ to treat a urinary infection and $9 \%$ to treat a gynaecological infection, it still remains a worrying percentage of those who use antibiotics incorrectly. Although it has previously been observed that a fairly large percentage of respondents know that the antibiotic is an antibacterial drug, that they addressed to a physician when faced with a major health problem and that they administer antibiotics at the recommendation of a physician, the percentage of those using antibiotics incorrectly for viral diseases is quite high (39\%), respectively for flu $21 \%$ and for throat pain, $18 \%$. There are even $3 \%$ and $2 \%$, respectively, who use antibiotics to treat headaches and rheumatic pains. All these considerations lead to the conclusion that there are people who do not make a clear and accurate correlation between the antibacterial medicine term and the conditions it treats.

The responses received at the next question of the survey indicated the frequency of use of antibiotics by patients (Figure 8 ).

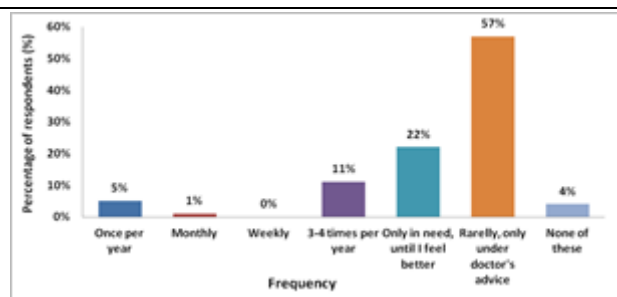

Figure 8.

The results obtained at the question: "How do you use antibiotics?"

Although $57 \%$ of respondents claim that use antibiotics as rarely as possible and at the doctor's indication, however $22 \%$ use them in need and only until they feel better and 11\% use antibiotics 3-4 times per year, which again indicate an irrational consumption of antibiotics.

The responses to the seventh question in the questionnaire reveal the issues concerning the duration of treatment (Figure 9).

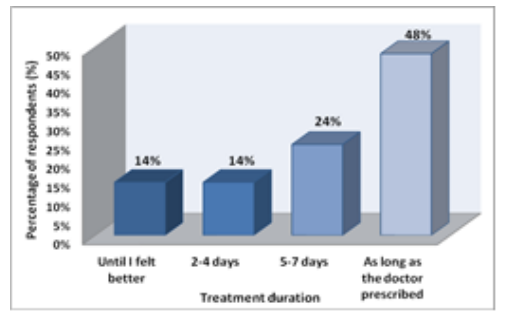

Figure 9.

The results obtained at the question: "How long have you followed antibiotic treatment?"

According to the results presented in Figure 9, most respondents $(48 \%)$ claimed that they administered antibiotics as long as the physician indicated, and a percentage of $24 \%$ followed the treatment for $5-7$ days, indicating a right situation in terms of duration. However, there are still quite a lot of respondents who have not respected the correct posology, namely $14 \%$ claimed that they took antibiotics for only $2-4$ days or when they felt better, they discontinued the treatment.

The next question in the survey questioned patients about how they acquire antibiotics: "From the pharmacy, did you get antibiotics based on the medical prescription?". According to the results obtained in survey, most of the patients procured antibiotics from the pharmacy based on the medical prescription $(67 \%)$, but in conditions in which in the country, for dispensing antibiotics, usually it is necessary that the patient presents a medical prescription, it remains an alarmingly high percentage of those who obtained antibiotics from the pharmacy without holding such a prescription (33\%). As an explanation for these results, it is worth mentioning that, in Romania, there is an exception regulated by the legislation of the emergency pharmaceutical 
services which stipulates that an antibiotic can be issued without a prescription for 1-3 days in case of some emergency situations, e.g. legal holidays or weekends. The questionnaire didn't contain questions about specific situations such as acute stage of the disease or the weekends/ holidays, therefore the results obtained may include also the patients found in these particular situations.

Question no. 9 was intended to highlight whether patients were advised by the pharmacist on the mode of administration and the potential inconvenience that may occur during the antibiotic treatment: „Did the pharmacists who dispensed antibiotics advice you concerning the administration mode and any inconvenience that may occur during treatment?". The results showed that $44 \%$ of the respondents were counselled by the pharmacist concerning the posology and the possible inconveniences that may occur during the treatment, but a fairly close percentage, i.e. $35 \%$ claimed that only in some cases they received this information and $21 \%$ of them argued they have never received this information. Because this may be one of the causes of non-compliance with the treatment duration, doses and, implicitly, irrational antibiotic use, this important issue requires an increased attention and an improvement in the pharmacist's attitude [3, 26].

The following two questions related to the possible side effects and how they have been corrected (Figure 10).

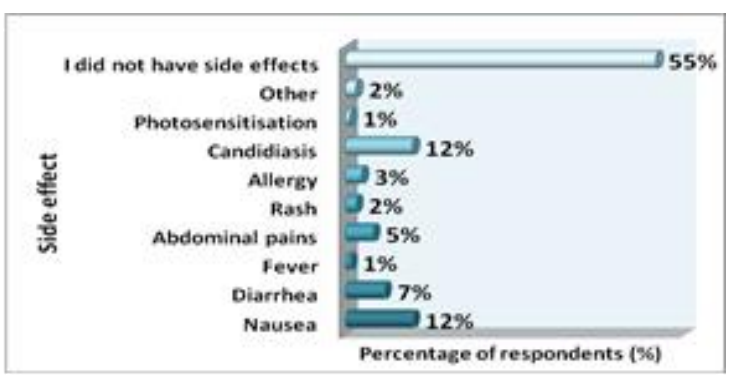

Figure 10.

The results obtained at the question: "During the administration of antibiotics, did you experience side effects? If yes, which ones?"

Most respondents claimed that they did not have side effects during the treatment with antibiotics (55\%); in an equal percentage of $12 \%$, the patients had nausea and candidiasis, $7 \%$ had diarrhea, 5\% abdominal pains and in a reduced percentage, the side effects were fever, rash, allergies, photosensitisation and others. As noted, the majority did not experience side effects, but $12 \%$ experienced candidiasis, from which it can be realized that patients either did not comply with the physician's advice to use a probiotic or an antifungal drug during treatment, how would proceed correctly, or perhaps they were not advised about this. Among the side effects that occurred during the antibiotic treatment were nausea and abdominal pains, which may be due, to a certain extent, to non-compliance with the appropriate administration mode of antibiotics. Even in this case, additional counselling would reduce many of the problems encountered during the antibiotic treatment.

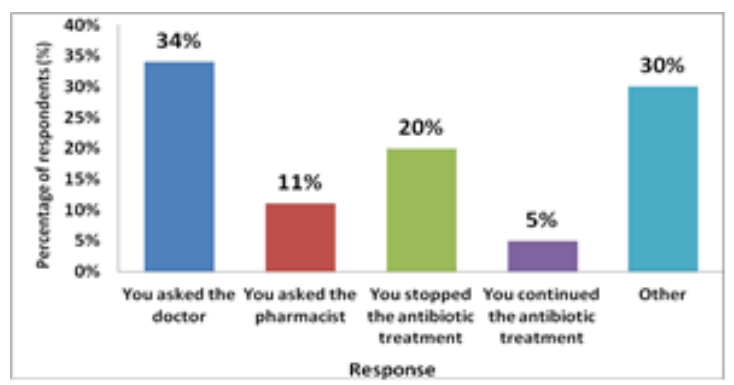

Figure 11.

The results obtained at the question: "How did you proceed in case of problems' occurrence during antibiotics administration?"

According to the results presented in Figure 11, if problems occurred during the antibiotic treatment, $34 \%$ of the respondents contacted the doctor, $30 \%$ solved otherwise the problem, $20 \%$ discontinued the treatment, $11 \%$ asked the pharmacist and $5 \%$ continued the treatment. Considering the fact that most of respondents did not experience very serious side effects, the decision of $20 \%$ of those who discontinued the treatment without consulting the doctor or the pharmacist is not justified due to the consequences that may arise from antibiotic giving up, when the treatment is absolutely necessary.

Continuing with the answers received to the twelfth and thirteenth questions, we found out whether patients were informed/ advised by the physician/ pharmacist about the risks of the irrational use of antibiotics and which they think are the most serious consequences of the irrational antibiotic use.

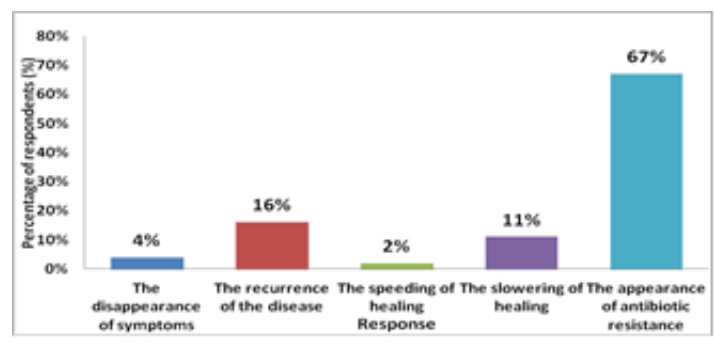

Figure 12.

The results obtained in question: "Which do you think are the worst consequences of the irrational use of antibiotics?"

According to the results obtained in question: "Have you been informed/warned by the physician/ pharmacist about the risks of irrational use (abusive consumption, non-compliance with the correct treatment regimen) of antibiotics?", it is noticed that the majority, in 
percentage of 52\%, was informed concerning the risk involved by the irrational use of antibiotics, fact proved by the very high percentage of those who know that a serious consequence of the irrational use of antibiotics is the installation of the bacterial resistance to antibiotics (67\%) (Figure 12). However, there remain many who claimed that they have not been informed about this issue, namely $48 \%$, which explains an irrational consumption of antibiotics and those who erroneously considered that the most serious consequences would be the disappearance of symptoms and the speeding up of healing and, not least, the unjustified use of antibiotics in the case of simple colds, sore throat or dental pain.

Antibiotic resistance is increasing at an alarming rate and is now widely recognised as a global issue that requires urgent attention. Despite several strategies being deployed, resistance levels are still of huge concern, and antibiotic resistance breakers (ARBs) represent a promising avenue of research to counter this $[5,18]$.

In order to contribute to decreasing the antibiotic resistance, some proposed measures include the need of improving the regulatory framework for antibiotic use and research globally [7]. The studies emphasize the need for global surveillance of the antibiotic consumption, to support policies to reduce antibiotic consumption and resistance, while providing access to these lifesaving drugs [16].

The questionnaire has in the end a section of mentions and suggestions from the respondents. This section includes opinions of respondents regarding the encountered situations related to the antibiotic use, their views on the attitudes of doctors and pharmacists and other issues they wanted to express. Some respondents replied that in the event of a misdiagnosis made by a physician solely based on the medical history of the patient (without medical tests or antibiogram), which led to the prescription of antibiotic treatment when it was unnecessary such a treatment, their health deteriorated, which cannot be neglected and should alert concerning the negative facet of the unjustified use of antibiotics. These not only do not lead to the healing of a condition that does not require such treatment, but on the contrary, administered when not needed, can lead to a worsening of the state of health. Antibiotics should be used only when absolutely necessary and at the advice of the physician, these being the ,last form of fight against bacteria and infections", in the opinion expressed by some respondents, which means that some patients are aware of the importance of a specialist consultation and the risk of inadequate consumption of antibiotics. Other opinions received in the questionnaire lead to consider that there are cases where the patient counselling, whether provided by the physician or the pharmacist, is insufficient or misunderstood by patients. These participants in the survey states that they use antibiotics as rarely as possible, and even when their doctor prescribes antibiotics for a more serious health problem, they prefer to use them as they see fit, i.e. "up to 2 - 3 times during treatment". In this case, it can be noticed the non-compliance with the posology and an informational deficiency regarding the risks involved in a chaotic treatment.

Based on the obtained results from the quantification of data and the received suggestions from respondents, it can be appreciated that the main cause of the irrational use of antibiotic is the administration of antibiotics in conditions that do not require such medication, because of the lack of knowledge and incapacity of some patients to make a correct correlation between the antibiotic term and the affections it treats, due sometimes to an insufficient counselling provided by physicians and pharmacists, on the posology and risks associated to antibiotics use.

Following the present research, a proposed solution to remedy these issues, an original, interactive and suggestive booklet was developed, in order to raise awareness and inform the population concerning the use of antibiotics, to be distributed in pharmacies.

\section{Conclusions}

An instrumental marketing research, based on a questionnaire, was used for the investigation of the current consumption of antibiotics in Romania, and more specifically, the observation and analysis of the antibiotic consumer and, implicitly, the procurement of antibiotics from the community pharmacies.

A current issue the population is facing more and more frequently is the alarming incidence of cases of increasing bacterial resistance to antibiotics. Irrational consumption of antibiotics is the main factor in the emergence of bacterial resistance.

The prudent use of antibiotics can contribute to the reduction or even stopping the development of resistant bacteria and ensure the effectiveness of antibiotics in the future.

Considering the fact that Romania is among the first countries in Europe concerning the consumption of antibiotics, it is very important to be aware of the risks to which those who irresponsibly consume antibiotics are exposed.

The questionnaire distributed in the investigation carried out comprised several questions and a section of suggestions, opinions, and mentions. The study comprised all counties in Romania and people aged over 18 years were questioned. As the result of the quantification and analysis of the data and the suggestions received from the respondents, 
it was pointed out that the main causes of the irrational consumption of antibiotics are the administration of antibiotics in conditions that not require such medication, because of the inability of the population to correlate clearly and correctly the term antibiotic with the conditions it treats, sometimes the insufficient counselling provided by physicians and pharmacists on the posology and the risks associated with the antibiotic use and, last but not least, the dispensing of antibiotics from community pharmacies, in some cases, in the absence of a medical prescription.

The solution proposed to remedy these problems consisted in producing and distributing an original, interactive and suggestive booklet, to help patients understand what is an antibiotic, which are the conditions that it treats and, not least, to help them to be aware of the risks of an irrational use of antibiotics.

\section{References}

1. Alanis AJ, Resistance to antibiotics: are we in the post-antibiotic era? Arch Med Res., 2005; 36(6): 697-705.

2. Basu S, Garg S, Antibiotic prescribing behavior among physicians: ethical challenges in resourcepoor settings. J Med Ethics Hist Med., 2018; 11: 14.

3. Boboia A, Research on applying risk management in the field of quality in order to improve the pharmacy activity. I. Applying quality management methods to highlight the causes that can lead to risks of errors in activities performed by the pharmacist in pharmacy. Farmacia, 2019; 67(6): 1106-1115.

4. Brolund A, Overview of ESBL-producing Enterobacteriaceae from a Nordic perspective. Infect Ecol Epidemiol., 2014; 4: 1-9.

5. Brown D, Antibiotic resistance breakers: can repurposed drugs fill the antibiotic discovery void? Nat Rev Drug Discov., 2015; 14(12): 821-832.

6. Călina D, Docea AO, Rosu L, Zlatian O, Rosu AF, Anghelina F, Rogoveanu O, Arsene AL, Nicolae AC, Drăgoi CM, Tsiaoussis J, Tsatsakis AM, Spandidos DA, Drakoulis N, Gofita E, Antimicrobial resistance development following surgical site infections. Mol Med Rep., 2017; 15(2): 681-688.

7. Chokshi A, Sifri Z, Cennimo D, Horng H, Global contributors to antibiotic resistance. J Glob Infect Dis., 2019; 11(1): 36-42.

8. Coculescu BI, Popescu D, Ionescu L, Dumitrescu G, Tantu MM, Necsulescu M, Paunescu A, Research on new patterns of antimicrobial resistant in bacterial pathogens identified in healthcareassociated infections. Rev Chim., 2019; 70(8): 2963-2967.

9. Colibaba D, The questionnaire - a valuable tool in the market research. Informatica Economica Journal, 2001; 5(3): 62-65, (available in Romanian).
10. Datculescu P, Marketing research. Brandbuilders Group, Bucharest, 2006, (available in Romanian).

11. Directorate-General for Health and Consumers, Directorate-General Communication „Research and Political Analysis" Unit of the European Commission, Antimicrobial resistance. Special Eurobarometer. TNS Opinion \& Social, Brussels, 2010, available at: http://ec.europa.eu.

12. Dumitraşcu V, Pharmacology: antimicrobial drugs. Ed. Vest, Timişoara, 2007, (available in Romanian).

13. European Centre for Disease Prevention and Control (ECDC), European Antibiotic Awareness Day (EAAD) - a European Health Initiative, available at: http://ecdc.europa.eu.

14. Feier BG, Florea A, Cristea C, Sandulescu R, Electrochemical detection and removal of pharmaceuticals in waste waters. Curr Opin Electrochem., 2018; 11: 1-11.

15. Gavrilas LI, Ionescu C, Balacescu O, Revnic C, Ciobarca D, Filip L, Boboia A, Miere D, Foods and food groups associated with colorectal cancer: a case-control study. Farmacia, 2018; 66(5): 846852.

16. Klein EY, Van Boeckeld TP, Martineza EM, Panta S, Gandraa S, Levin SA, Goossensh H, Laxminarayana R, Global increase and geographic convergence in antibiotic consumption between 2000 and 2015. PNAS, 2018; 115(15): E3463E3470.

17. Kotler P, Keller KL, Marketing management, $12^{\text {th }}$ Edition. Pearson Prentice Hall, New Jersey, 2006.

18. Laws M, Shaaban A, Rahman KM, Antibiotic resistance breakers: current approaches and future directions. FEMS Microbiol Rev., 2019; 43(5): 490516.

19. Machowska A, Lundborg CS, Drivers of irrational use of antibiotics in Europe. Int $J$ Environ Res Public Health., 2019; 16(1): 1-14.

20. Matinca D, Antibiotics. Iuliu Haţieganu University Medical Publishing House, Cluj-Napoca, 2002, (available in Romanian).

21. Oniga O, Tiperciuc B, Nastasă C, Ionuţ I, Chemistry and action of antibacterial antibiotics. Iuliu Haţieganu University Medical Publishing House, Cluj-Napoca, 2013, (available in Romanian).

22. Pitout JD, Laupland KB, Extended-spectrum betalactamase-producing Enterobacteriaceae: An emerging public-health concern. Lancet Infect Dis., 2008; 8(3): 159-166.

23. Safrany N, Monnet LD, Antibiotics obtained without a prescription in Europe. Lancet Infect Dis., 2012; 12(3): 182-183.

24. Stana A, Ionuţ I, Tiperciuc B, Nastasă C, Marc G, Oniga $\mathrm{O}$, Antibacterials authorized in the $21^{\text {st }}$ century. In Medicines of the $21^{\text {st }}$ century and modern therapies, Iuliu Haţieganu University Medical Publishing House, Cluj-Napoca, 2019, (available in Romanian).

25. Todar $\mathrm{K}$, Bacterial resistance to antibiotics. In: Todar's Online Textbook of Bacteriology, available at: http://textbookofbacteriology.net. 
FARMACIA, 2020, Vol. 68, 4

26. Turcu-Stiolica A, Subtirelu MS, Taerel AE, Boboia A, Berbecaru-Iovan A, Analysis of financial losses due to poor adherence of patients with chronic diseases and their impact on health economics. In Financial management from an emerging market perspective, InTech, 2018.
27. Turcu-Stiolica A, Taerel AE, Turcu-Stiolica R, Identifying and measuring compliance and adherence in antidepressants taking. Procedia Econ Financ., 2014; 15: 836-839.

28. Webster P, Antibiotic overprescribing a growing problem. CMAJ, 2017; 189(5): E222. 